Fajar Historia: Jurnal Ilmu Sejarah dan Pendidikan

Volume 2 nomor 2, Desember 2018, Hal. 35 - 45

\title{
PENGARUH MODEL PEMBELAJARAN KONTEKSTUAL TERHADAP HASIL BELAJAR SEJARAH SISWA KELAS X MA NW LENEK LAUQ
}

\author{
${ }^{1}$ Erni Budiarti, ${ }^{2}$ Zidni, ${ }^{3}$ Bambang Eka Saputra \\ ${ }^{1,2,3}$ Universitas Hamzanwadi \\ budiarti@gmail.com, zidni@gmail.com
}

\begin{abstract}
So far there are still many teachers using methods that are not appropriate such as conventional learning models, learning is dominated by teachers. The learning method used tends to be monotonous and teacher-centered. These conditions can also make students passive and the expected learning process will not occur. When the learning process does not occur, learning outcomes will not be obtained as expected. For this reason, we need a method that provides space for students to be able to construct the meaning of the historical events they learned to then be able to connect with their lives. This study aims to determine the effect of contextual learning models on student learning outcomes in historical subjects Class X MA NW Lenek Lauq. This type of research is research using Quasi Experimental Design. The research sample was students of class X MA NW Lenek Lauq. 30 students as experimental class, 30 students as control class. The sample technique used simple random sampling and instruments used multiple choice tests. The analysis requirements test was carried out by Chi-square data normality test, while data analysis was performed with t-test. Based on the results of data analysis, the average value of the experimental group was 78.1 and the control group was 61.1. Then from the results of the hypothesis obtained tcount abel $t$ table is $14,049>2,002$, so that the conclusions in this study are contextual learning models affect the results of history learning at class X MA NW Lenek Lauq in academic year 2018/2019.
\end{abstract}

Keyword: Contextual Teaching And Learning, Learning Outcome.

\begin{abstract}
Abstrak
Pembelajaran konvensional dianggap sudah tidak relevan lagi dengan kebutuhan masyarakat. Selama ini masih banyak ditemukan guru menggunakan metode yang kurang tepat seperti model pembelajaran konvensional, pembelajaran didominasi oleh guru. Metode pembelajaran yang digunakan cenderung monoton dan berpusat pada guru seperti penggunaan metode ceramah dan mencatat yang tentunya tidak bisa melibatkan siswa secara utuh sehingga menyebabkan pembelajaran menjadi membosankan. Kondisi tersebut dapat membuat peserta didik menjadi pasif dan proses belajar yang diharapkan tidak akan terjadi. Ketika proses belajar tidak terjadi, maka tidak akan didapatkan hasil pembelajaran
\end{abstract}


seperti yang diharapkan. Untuk itu, diperlukan suatu metode yang memberikan ruang bagi siswa untuk dapat mengkonstruksi makna peristiwa sejarah yang dipelajarinya untuk kemudian dapat dihubungkan dengan kehidupannya. Penelitian ini bertujuan untuk mengetahui pengaruh Model pembelajaran kontekstual terhadap hasil belajar siswa pada mata pelajaran sejarah Kelas X MA NW Lenek Lauq. Jenis penelitian ini adalah penelitian dengan menggunakan True Eksperimental Design. Sampel penelitian adalah siswa kelas X MA NW Lenek Lauq. 30 siswa sebagai kelas eksperimen, 30 siswa sebagai kelas kontrol. Teknik sampel yang digunakan adalah simple random sampling dan instrument yang digunakan dalam bentuk test pilihan ganda. Uji persyaratan analisis dilakukan dengan uji normalitas data dengan Chi-kuadrat dan uji homogenitas data dengan uji Bartlet, sedangkan analisis data dilakukan dengan statistik inferensial parametrik uji t-test. Berdasarkan hasil analisis data diperoleh nilai rata-rata kelompok eksperimen 78,1 dan kelompok kontrol 61,1 . Kemudian dari hasil hipotesis diperoleh thitung $>$ ttabel yaitu 14,049>2,002, sehingga kesimpulan dalam penelitian ini yaitu model pembelajaran kontekstual berpengaruh terhadap hasil belajar sejarah siswa kelas X MA NW Lenek Lauq tahun pelajaran $2018 / 2019$.

Kata Kunci : Pembelajaran Kontekstual, Hasil Belajar.

\section{PENDAHULUAN}

Pendidikan adalah salah satu unsur yang sangat penting demi kemajuan suatu bangsa, karna pendidikan merupakan salah satu faktor untuk mengembangkan sumber daya manusia yang ada di suatu negara. Pendidikan merupakan sarana mutlak yang di pergunakan untuk mewujudkan masyarakat madani yang mampu menguasai, mengembangkan, mengendalikan dan memanfaatkan ilmu pengetahuan dan tekhnologi. Tujuan dari pendidikan itu sendiri adalah mencerdaskan kehidupan bangsa. Oleh karna itu, pendidikan tidak lepas dari ilmu pengetahuan dan wajib hukumnya untuk menuntut ilmu sampai akhir hayat. Selain itu pada pasal 31 ayat 5 mengamanahkan agar pemerintah memajukan ilmu pengetahuan dan teknologi dengan menjunjung tinggi nilai-nilai agama dan persatuan bangsa untuk kemajuan peradaban serta kesejahteraan manusia.

UU No. 20 Tahun 2003 tentang Sistem Pendidikan Nasional (Sisdiknas), menjelaskan bahwa pendidikan adalah usaha sadar dan terencana untuk mewujudkan suasana belajar dan proses pembelajaran agar peserta didik secara aktif mengembangkan potensi dirinya untuk memiliki kekuatan spiritual keagamaan, pengendalian diri, kepribadian, kecerdasan, akhlak mulia, serta keterampilan yang di perlukan dirinya dan 
Pengaruh Model Pembelajaran Kontekstual.....Erni Budiarti dkk

masyarakatnya. Dengan demikian, belajar dan pembelajaran menjadi hal yang fundamental dalam pendidikan.

Belajar merupakan suatu proses yang dialami peserta didik melalui interaksinya dengan lingkungan. Lingkungan yang dimaksud adalah segala unsur yang terdapat dalam pembelajaran yang sudah dipersiapkan agar kegiatan belajar tersebut terlaksana, yakni guru, teman, ruang kelas dan bahan pembelajaran. Hal tersebut juga dikemukakan Susanto (2016: 4) bahwa belajar adalah "suatu aktivitas mental yang berlangsung dalam interaksi aktif antara seseorang dengan lingkungan, dan menghasilkan perubahan-perubahan dalam pengetahuan, pemahaman, keterampilan dan nilai yeng relatif bersifat konstan."

Berbagai perubahan yang diakibatkan oleh perkembangan ilmu pengetahuan dan teknologi memberikan dampak terhadap perubahan tuntutan masyarakat sehingga menuntut relevansi dari dunia pendidikan. Pembelajaran model lama (konvensional) dianggap sudah tidak relevan lagi dengan kebutuhan masyarakat. Selama ini masih banyak ditemukan guru menggunakan metode yang kurang tepat seperti model pembelajaran konvensional, pembelajaran didominasi oleh guru, dimana guru menjadi satu-satunya sumber belajar yang dianggap mengetahui segalanya, sehingga pembelajaran pun diwarnai dengan transfer pengetahuan dari guru kepada peserta didik. Metode pembelajaran yang digunakan cenderung monoton dan berpusat pada guru seperti penggunaan metode ceramah dan mencatat yang tentunya tidak bisa melibatkan siswa secara utuh sehingga menyebabkan pembelajaran menjadi membosankan. Tentunya kondisi tersebut juga dapat membuat peserta didik menjadi pasif dan proses belajar yang diharapkan tidak akan terjadi. Ketika proses belajar tidak terjadi, maka tidak akan didapatkan hasil pembelajaran seperti yang diharapkan.

Inti proses pembelajaran tidak lain adalah kegiatan belajar peserta didik dalam mencapai suatu tujuan pembelajaran yakni perubahan perilaku baik pengetahuan, sikap maupun keterampilan. Semua itu termaktub dalam Undang-Undang Nomor 20 tahun 2003 tentang Sistem Pendidikan Nasional yakni "mengembangkan potensi peserta didik agar menjadi manusia yang beriman dan bertakwa kepada Tuhan Yang Maha Esa, berakhlak 
mulia, sehat, berilmu, cakap, kreatif, mandiri, dan menjadi warga negara yang demokratis serta bertanggung jawab."

Untuk dapat mencapai tujuan tersebut, maka sudah semestinya proses belajar itu terjadi secara optimal. Oleh karena itu, guru sebagai salah satu tokoh yang berperan dalam menyiapkan pembelajaran, sudah seharusnya mendesain dan melaksanakan pembelajaran yang dapat menggali potensi peserta didik dalam mencapai tujuan pendidikan. Peran guru dalam intraksi belajar mengajar tidak terlepas dari adanya pembelajaran. Pembelajaran pada dasarnya adalah seperangkat peristiwa yang mampu mengondisi, mendorong, melayani, dan mengarahkan kegiatan belajar siswa. Sebab itulah kegiatan pembelajaran, sudah seharusnya disertai dengan kegiatan belajar karena antara keduanya selayaknya memiliki hubungan secara seimbang. Tetapi dalam kenyataannya, masih sering di temukan adanya pembelajaran yang masih bertumpu pada kegiatan mengajar dan bukan pada pembelajaran yang benar-benar mampu menciptakan proses belajar. Situasi demikian terjadi karena pada umumnya guru hanya meletakkan dirinya sebagai sumber informasi dan melupakan kemungkinan fungsinya sebagai sumber pendorong, penyedia, pengelola, dan penilaian kepada siswa. dari hasil wawancara dengan guru mata pelajaran sejarah di MA NW Lenek Lauq, kegiatan siswa dalam pembelajaran Sejarah masih kurang aktif. Hal ini terlihat dari jarangnya siswa mengeluarkan ide-ide/gagasan karena metode pengajaran yang dilakukan masih menerapkan metode konvensional. Metode pembelajaran seperti ini menyebabkan kurangnya perhatian, minat, dan motivasi siswa dalam mengikuti pelajaran yang pada akhirnya menyebabkan tujuan pembelajaran tidak tercapai.

Sebagaimana yang telah ditetapkan Unesco bahwa belajar tidak hanya untuk mengetahui (learning to know) tetapi juga learning to do, learning to be dan learning to live together (Laksana, 2016). Berdasarkan hal tersebut, dan rumusan tujuan pendidikan nasional, maka belajar yang sebenarnya akan terjadi jika peserta didik mengalami dan melakukan secara langsung segala aktivitas yang merupakan proses belajarnya. Peserta didiklah yang secara aktif mencari, menggali dan menemukan sendiri sehingga betul-betul menjadi miliknya sendiri yang akan dimanfaatkan untuk mengatasi berbagai persoalan dalam hidupnya. 
Pembelajaran sejatinya adalah proses penjelajahan terbimbing, memberikan ruang bagi siswa untuk mengalami sendiri, terlibat secara penuh dalam menemukan inti materi yang dipelajari, yang kemudian menghubungkannya dengan situasi kehidupan siswa, sehingga hasil belajar menjadi bermakna dan dapat diterapkan dalam kehidupan siswa. Selama ini, sebagian besar siswa "tidak dapat menghubungkan apa yang telah mereka pelajari dengan cara pemanfaatan pengetahuan tersebut dikemudian hari" (Gafur, 2003). Apalagi pembelajaran sejarah yang notabenenya adalah belajar tentang masa lalu. Banyak anggapan yang mengemuka bahwa belajar sejarah tidak relevan lagi dengan konteks kehidupan sekarang.

Belajar sejarah tidak sesederhana menghafal nama, tahun, peristiwa. Tapi belajar sejarah "menyangkut penilaian, kepedulian, dan kewaspadaan. Sejarah adalah persoalan kesinambungan dan perubahan yang daripadanya kita dapat belajar. Dari belajar sejarah, kita bisa memahami masa lalu untuk membuat perubahan di masa kini serta mampu memetakan masa depan" (Wineberg, 2006). Oleh sebab itulah, peserta didik perlu dilatih untuk mempelajari peristiwa, bukan hanya dengan sekedar membaca teks sejarah, tetapi dapat memahami isinya dengan baik, dapat mengkonstruksi makna dari peristiwa yang pada akhirnya dapat menghubungkannya dengan kehidupan masa kini peserta didik.

Tentunya hal tersebut memberikan tantangan tersendiri bagi guru untuk mencari metode yang memberikan ruang bagi siswa untuk dapat mengkonstruksi makna peristiwa sejarah yang dipelajarinya untuk kemudian dapat dihubungkan dengan kehidupannya. Salah satu metode pembelajaran yang dapat diterapkan adalah Contekstual Teaching Learning (CTL). Menurut Sihono (2004), pembelajaran kontekstual (Contextual Teaching and Learning) adalah konsep belajar yang membantu guru mengaitkan antara materi yang diajarkannya dengan situasi dunia nyata siswa dan mendorong siswa membuat hubungan antara pengetahuan yang dimilikinya dengan penerapannya dalam kehidupan mereka sehari-hari. Model pembelajaran ini menjadikan hasil belajar lebih bermakna bagi siswa, sehingga hasil belajar yang sesuai dengan tujuan pendidikan dapat dicapai.

Dalam banyak hasil penelitian yang telah dilakukan sebelumnya, pembelajaran CTL ini memberikan pengaruh yang positif terhadap hasil belajar siswa (Kristanti, 2010; 
Pengaruh Model Pembelajaran Kontekstual.....Erni Budiarti dkk

Sardin, 2018) Dalam penelitian lain yang dilakukan oleh Suwandi (2016) bahwa strategi Contextual Teaching and Learning (CTL) mampu meningkatkan pengetahuan dan taraf berpikir siswa.

Pembelajaran kontekstual (Contextual Teaching and Learning - CTL) sebagai model pembelajaran untuk membangun pengetahuan dan keterampilan berpikir melalui bagaimana belajar dikaitkan dengan situasi nyata di lingkungan sekitar peserta didik, sehingga hasilnya lebih bermakna (Rianto, 2006: 14). CTL memunculkan tiga pemahaman pokok, yaitu: Pertama, CTL menekankan kepada proses keterlibatan siswa untuk menemukan materi, artinya proses belajar diorientasikan pada proses pengalaman secara langsung. Jadi, proses belajar dalam konteks CTL tidak mengharapkan agar siswa hanya menerima pelajaran, akan tetapi proses mencari dan menemukan sendiri materi pelajaran. Kedua, CTL mendorong agar siswa dapat menemukan hubungan antara materi yang dipelajari dengan situasi kehidupan nyata, artinya siswa dituntut untuk dapat menangkap hubungan antara pengalaman belajar di sekolah dengan kehidupan nyata yang dialaminya. Hal ini sangat penting, sebab dengan dapat mengorelasikan materi yang ditemukan dengan kehidupan nyata, bukan saja bagi siswa materi itu akan bermakna secara fungsional, akan tetapi materi yang dipelajarinya akan tertanam erat dalam memori otak siswa, sehingga tidak akan mudah dilupakan. Ketiga, CTL mendorong siswa untuk dapat menerapkannya dalam kehidupan nyata, artinya CTL bukan hanya mengharapkan siswa dapat memahami materi yang dipelajarinya, akan tetapi bagaimana materi pelajaran itu dapat mewarnai perilakunya dalam kehidupan sehari-hari. Materi pelajaran dalam konteks CTL bukan untuk ditumpuk di otak dan kemudian dilupakan, akan tetapi sebagai bekal mereka untuk berkompetisi di kehidupan yang sesungguhnya (Suwandy, 2016).

Berdasarkan uraian tersebut di atas, peneliti ingin mencoba untuk menerapkan metode pembelajaran Contekstual Teaching Learning (CTL) untuk melihat pengaruhnya terhadap hasil belajar sejarah siswa Kelas XMA NW Lenek LauqTahun Pelajaran 2018/2019. Penelitian ini diharapkan mampu menjawab tantangan bagi guru maupun siswa dalam belajar sejarah, sehingga dapat menjadi alternatif model pembelajaran yang dapat 
Pengaruh Model Pembelajaran Kontekstual.....Erni Budiarti dkk

dipilih untuk memperbaiki kualitas pembelajaran yang akan meningkatkan hasil belajar sejarah siswa.

\section{METODE PENELITIAN}

Jenis penelitian yang di gunakan dalam penelitian ini adalah penelitian eksperimen. Penelitian eksperimen merupakan penelitian yang menerapkan prinsip-prinsip penelitian laboratorium, terutama dalam pengontrolan terhadap hal-hal yang mempengaruhi jalannya eksperimen (Sukmadinata, 2012: 57).

Penelitian eksperimen merupakan penelitian yang dimaksudkan untuk mengetahui ada tidaknya akibat dari "sesuatu" yang dikenakan pada subjek yang diteliti. Dengan kata lain penelitian eksperimen mencoba meneliti ada tidaknya hubungan sebab akibat. Caranya adalah dengan membandingkan satu atau lebih kelompok eksperimen yang diberi perlakuan dengan satu atau lebih kelompok pembanding yang tidak menerima perlakuan (Prehati, 2013).

Pada penelitian ini, pendekatan yang di gunakan adalah pendekatan kuantitatif dan desain penelitian yang digunakan dalam penelitian ini adalah quasi experimental design (eksperimen semu) semua lingkungan yang mempengaruhi hasil penelitian tidak dapat dikendalikan. Desain yang digunakan adalah Posttest-Only Control Design maksudnya suatu bentuk desain penelitian ini yang mengukur kemampuan prestasi belajar siswa setelah melakukan proses pembelajarann di karenakan bahwa kemampuan awal siswa pada kedua sampel tersebut sama (Suharsimi Arikunto, 2006), karena setelah peneliti melakukan pre tes pada sampel penelitian, diperoleh hasil yang relative sama. Pada desain ini, satu kelas diperlakukan sebagai kelompok eksperimen dan satu kelas lainnya sebagai kelompok kontrol. Pada kelompok eksperimen diterapkan pembelajaran kontekstual dan pada kelompok control dibelajarkan dengan metode yang biasa dilakukan sehari-hari.

Subjek dalam penelitian ini adalah siswa kelas X MA NW Lenek Lauq Tahun Pelajaran 2018/2019. Populasi dalam penelitian ini yaitu kelas X MA NW Lenek Lauq Tahun Pelajaran 2018/2019. Sampel dalam penelitian ini sebanyak 60 siswa. Dengan demikian diperoleh 30 siswa sebagai kelas eksperimen dan 30 siswa sebagai kelas kontrol. 
Instrumen yang digunakan dalam penelitian ini berbentuk tes objektif dengan bentuk soal pilihan ganda. Tes objektif yang digunakan pada penelitian ini adalah tes plihan ganda dengan jumlah soal 50 soal tentang zaman pra-aksara (zaman sebelum mengenal tulisan) untuk mengetahui hasil belajar siswa. Sebelum digunakan, tes terlebih dahulu diuji validitas dan reliabilitasnya. Selanjutnya data yang terkumpul melaui hasil post-test dianalisis menggunakan uji t- tes yang sebelumnya telah diuji prasyarat yaitu uji normalitas data.

\section{HASIL PENELITIAN DAN PEMBAHASAN}

Data yang terkumpul dalam penelitian ini terdiri dari data tes hasil belajar siswa pada mata pelajaran Sejarah siswa kelas X. Berdasarkan hasil penelitian mengenai pengaruh model pembelajaran kontekstual terhadap hasil belajar sejarah siswa kelas X MA NW Lenek Lauq yakni nilai kelas eksperimen dengan banyak siswa 30 orang dan diajarkan dengan model pembelajaran kontekstual dengan nilai rata-rata post-test 78,1 . Selanjutnya kelas kontrol dengan banyak siswa 30 orang dan diajarkan dengan metode ceramah (konvensional) nilai rata-rata post-test 61,1. Data dalam tabel diatas menunjukkan bahwa nilai rata - rata penerapan pembelajaran dengan model pembelajaran kontekstual lebih tinggi dibanding penerapan pembelajaran menggunakan metode konvensional di MA NW Lenek Lauq tahun pelajaran 2018/2019. Untuk lebih jelasnya dapat dilihat pada tabel berikut ini:

Tabel 1. Hasil post test kelompok eksperimen dan kontrol

\begin{tabular}{|l|l|l|}
\hline No & Kelas & Rata - rata \\
\hline 1 & Eksperimen & 78,1 \\
\hline 2 & Kontrol & 61,1 \\
\hline
\end{tabular}

Setelah didapat hasil belajar dari kelas eksperimen dan kelas kontrol, selanjutnya peneliti melakukan uji normalitas menggunakan uji chi-kuadrat yaitu pada kelas eksperimen diperoleh kesimpulan bahwa data berdistribusi normal, demikian juga pada kelas kontrol diperoleh kesimpulan bahwa data berdistribusi normal. 
Setelah dilakukan perhitungan pada masing-masing kelas eksperimen dan kelas kontrol diperoleh hasil nilai thitung $=14,059$. Apabila thitung dikonsultasikan pada tabel $\mathrm{dk}=(\mathrm{n} 1+\mathrm{n} 2)-2=58$ pada taraf signifikan $(\alpha)=0,05$ diperoleh ttabel $=2,002$. Ternyata thitung lebih besar daripada ttabel $(14,059>2,002)$, maka hipotesisnya berbunyi "Terdapat pengaruh yang positif dan signifikan model pembelajaran kontekstual terhadap hasil belajar sejarah siswa kelas X MA NW Lenek Lauq tahun pelajaran 2018/2019.

Berdasarkan hasil penelitian yang telah dilakukan di MA NW Lenek Lauq dengan pokok bahasan "zaman pra-aksara (sebelum mengenal tulisan)" dengan menggunakan model pembelajaran kontekstual yang diterapkan pada kelas eksperimen dan metode konvensional yang diterapkan pada kelas kontrol, diperoleh bahwa ada pengaruh positif yang signifikan, artinya penggunaan model pembelajaran kontekstual lebih baik dari pembelajaran dengan menggunakan metode konvensional.

Temuan pada saat penelitan menunjukkan bahwa pembelajaran dengan menggunakan metode kontekstual lebih efektif dibandingkan dengan metode konvensial. Pada kelas eksperimen siswa yang dibelajarkan dengan menggunakan metode kontekstual, siswa terlibat secara aktif dalam proses pembelajaran dan guru hanya berperan sebagai fasilitator untuk mengarahkan siswa. Metode pembelajaran ini memberikan kesempatan siswa untuk melakukan eksplorasi terhadap sumber-sumber belajar untuk menemukan sendiri pengetahuan mereka.

Dari kegiatan diskusi yang dilakukan, dalam pembelajaran ini siswa terlihat antusias dalam menyampaikan pikiran mereka walaupun masih sebatas menjawab pertanyaan yang diajukan oleh temannya. pembelajaran ini memberikan kesempatan yang luas kepada siswa untuk menggali potensi mereka dengan mengeksplor semua sumber belajar yang disediakan untuk membangun pengetahuan mereka, yang kemudian dengan dibantu oleh guru mampu mengaitkan apa yang dipelajari dengan situasi kehidupan nyata. Hal ini sesuai dengan ruh pembelajaran kontekstual yakni pembelajaran kontekstual memandang bahwa proses belajar benar-benar berlangsung hanya jika siswa mampu memproses atau mengkonstruksi sendiri informasi atau pengetahuan sedemikian rupa sehingga pengetahuan tersebut menjadi bermakna sesuai dengan kerangka berpikir mereka. 
Pendekatan pembelajaran yang demikian ini berasumsi bahwa secara alamiah proses berpikirdalam menemukanmakna sesuatu itu bersifat kontekstua1, dalam arti ada kaitannya dengan lingkungan, pengetahuan, dan pengalaman yang telah mereka miliki (perbendaharaan ingatan, pengalaman, respons) (Gafur, 20023). Selain itu, pada model pembelajaran ini peran guru sebagai fasilitator, memberikan kesempatan kepada siswa untuk menemukan atau menerapkan sendiri ide-ide dan mengajak siswa agar dengan menyadari menggunakan strategi-strategi mereka sendiri yang pada akhirnya ada kesempatan cukup bagi siswa untuk mempertahankan dan mempertanggung jawabkan pendapatnya.

Hasil penelitian ini juga didukung juga oleh hasil penelitian yang di lakukan oleh Wira Silvianti pada tahun 2014 dengan judul penelitian "penerapan pendekatan kontekstual (CTL) berbasis kecerdasan visual dalam pembelajaran Matematika pada siswa kelas VII SMPN 1 Batusangkar" dengan hasil penelitian: melalui pendekatan pembelajaran kontekstual (CTL) siswa lebih terlibat dalam kegiatan pembelajaran dan hasil belajar siswa lebih baik. pada penelitian ini Wira Silvianti mencoba memanfaatkan kecerdasan visual siswa dalam penerapannya. Lain halnya dengan penelitian Wira Silvianti, penulis ingin meneliti tentang hasil belajar Sejarah siswa dengan penerapan model pembelajaran kontekstual (CTL).

\section{KESIMPULAN}

Berdasarkan pemaparan di atas dapat disimpulkan bahwa ada pengaruh model pembelajaran kontekstual terhadap hasil belajar sejarah siswa kelas X MA NW Lenek Lauq pada materi zaman pra-aksara (sebelum mengenal tulisan) tahun pembelajaran 2018/2019. Model pembelajaran ini mampu membangkitkan keaktifan siswa sehingga dapat terlibat secara langsung dalam mengonstruksi pengetahuannya dan melalui bimbingan guru dapat menghubungkannya dengan situasi kehidupan nyata yang dihadapi siswa.

\section{DAFTAR PUSTAKA}

Ari, 2013. Undang-Undang Pendidikan. Yogyakarta: Pustaka Mahardika. 
Pengaruh Model Pembelajaran Kontekstual.....Erni Budiarti dkk

Arikunto, S. 2006. Prosedur Penelitian: Suatu Pendekatan Praktek. Yogyakarta: Rineka Cipta.

Gafur, A. 2003. Penerapan Konsep Dan Prlnsip Pembelajaran Kontekstual (Contextual Teaching And Learning) Dan Desain Pesan Dalam Pengembangan Pembelajaran Dan Bahan Ajar. Cakrawala. Pendidikin (3):273-289.

Kristanti, W. 2010. Pengaruh Metode Pembelajaran Kontekstual Terhadap Hasil Belajar IPS Geografi Kelas VIII SMPN 18 Balikpapan Ditinjau Dari Motivasi Belajar Siswa Tahun Pelajaran 2009/2010. Tesis. Surakarta: Universitas Sebelas Maret.

Laksana, S.D. Integrasi Empat Pilar Pendidikan (Unesco) Dan Tiga Pilar Pendidikan Islam. Diakses pada 12 September 2018. Http://media.neliti.com/media/publication/56566ID-none.pdf

Prehati, N. 2013. Pengertian Penelitian Eksperimen. Skripsi Tidak Diterbitkan. IAIN Salatiga.

Sihono, T. 2004. Contextual Teaching And Learning (CTL) Sebagai Model Pembelajaran Ekonomi Dalam KBK. Jurnal Ekonomi \& Pendidikan, 1(1): 63-83.

Sukmadinata, N. S. 2012. Metode Penelitian Pendidikan. Bandung: PT. Remaja Rosdakarya.

Surdin. 2018. The Effect of Contextual Teaching and Learning (CTL) Models on learning outcomes of Social Sciences of the material of forms the face of the earth on Class VII of Junior High School. International Journal of Education and Research, 6 (3): 57-64.

Susanto, A. 2016. Teori Belajar Dan Pembelajaran. Jakarta: Prenada Media Group.

Suwandi, F.I. 2016. Strategi Pembelajaran Contextual Teaching And Learning Untuk Meningkatkan Keterampilan Berpikir Tingkat Tinggi. Prosiding Seminar Nasional Pendidikan IPA "Mengembangkan Keterampilan Berpikir Tingkat Tinggi Melalui Pembelajaran IPA” Penerbit: S2 IPA UNLAM PRESS., Edisi: Oktober 2016., ISBN: 978-602-60213-0-4http://www.s2ipa.unlam.ac.id/category/publikasilmiah/proceeding/seminar-nasional-pendidikan-ipa-2016/ 